\title{
Root production and belowground seagrass biomass
}

\author{
Carlos M. Duarte ${ }^{1, *}$, Martín Merino ${ }^{2}$, Nona S. R. Agawin ${ }^{3}$, Janet Uri ${ }^{3}$, \\ Miguel D. Fortes ${ }^{3}$, Margarita E. Gallegos ${ }^{4}$, Nùria Marbá ${ }^{5}$, Marten A. Hemminga ${ }^{5}$ \\ ${ }^{1}$ Centro de Estudios Avanzados de Blanes, CSIC, Camí de Santa Bárbara s/n, E-17300 Blanes, Girona, Spain \\ ${ }^{2}$ Instituto de Ciencias del Mar y Limnología, Universidad Nacional Autónoma de México, 04510 México D.F., México \\ ${ }^{3}$ Marine Science Institute, CS, University of The Philippines, Diliman, Quezon City, The Philippines \\ ${ }^{4}$ Departamento de Hidrobiología, Universidad Autonoma Metropolitana - Iztapalapa, Michoacán y Purísima, Col. Vicentina, \\ AP 55-535, 09340 México D.F., México \\ ${ }^{5}$ Netherlands Institute of Ecology, Centre for Estuarine and Coastal Ecology, Vierstraat 28, 4401 EA Yerseke, \\ The Netherlands
}

\begin{abstract}
The root and rhizome biomass of the seagrass species present in 3 mixed and 2 monospecific meadows representative of different floras (Spanish Mediterranean, Mexican Caribbean, Kenyan coast, and the South China Sea off The Philippines) was examined to test for the existence of general patterns in the distribution of their biomass in the sediments, and to test a simple approach based on age determinations to estimate root production. The thickness of the roots was scaled to the thickness of the seagrass rhizomes $(r=0.92, p<0.001)$. Root and rhizome biomass were high $(>100$ and $>200 \mathrm{~g} \mathrm{DW} \mathrm{m}^{-2}$, respectively) for the mixed meadows examined; these belowground structures had a projected surface area often exceeding $1 \mathrm{~m}^{2} \mathrm{~m}^{-2}$ when roots and rhizomes were considered together, and they formed a dense web of root material comprising several hundred meters per square meter. Belowground biomass showed considerable vertical stratification within the sediments, with a tendency for the larger species to extend deeper into the sediments than smaller ones. This tendency for segregation should reduce the potential interspecific competition for sediment resources, which is likely to be greater in the uppermost layers, where the belowground biomass is more evenly distributed among species. The rate of adventitious root production on vertical shoots varied from species that produced a root on almost every node to species that produced 1 adventitious root for every 10 nodes. Root production - both on horizontal rhizomes and vertical shoots - was substantial, with the combined root production approaching, or exceeding, $1000 \mathrm{~g} \mathrm{DW} \mathrm{m}^{-2} \mathrm{yr}^{-1}$ The resulting root turnover was quite high, with most values ranging between 2 and $10 \mathrm{yr}^{-1}$, indicative of a characteristic turnover time of months for the root compartment. The estimates of root production derived here of ten exceed those of rhizome production and reach values comparable to leaf production, clearly demonstrating that root production is an important component (up to $50 \%$ ) of total seagrass production.
\end{abstract}

KEY WORDS: Seagrass Roots Rhizomes Biomass P Production

\section{INTRODUCTION}

The realization of the importance of fine roots as components of the biomass and production of land plants, and their response to resource availability (Gross et al. 1993, Hendricks et al. 1993), is rapidly expanding, drawing considerable attention to the study of plant roots and efforts to develop methods to

-E-mail: duarte@ceab.csic.es assess their production (Hendricks et al. 1993, Hemminga et al. 1996). In parallel, there is growing evidence that belowground seagrass organs play an important role in the nutrition, anchoring, and spreading of seagrasses (e.g McRoy \& Barsdate 1970, Kuo \& McComb 1989, Duarte \& Sand-Jensen 1990, Duarte 1991), and that belowground biomass often dominates the total plant biomass of seagrass communities (i.e. seagrass belowground to aboveground biomass ratios of generally >1. Stevenson 1988, Kuo \& McComb 1989 , 
Duarte \& Chiscano in press). Yet, there is a major imbalance between our knowledge of the development of aboveground and that of belowground structures in seagrass communities. Studies of seagrass biomass and production generally neglect belowground biomass and production, which a recent survey (Duarte \& Chiscano in press) showed to be included in oniy 14 and $29 \%$ of the published estimates of seagrass biomass and production, respectively, and even those studies that do consider the belowground compartment generally include only the rhizome fraction.

The belowground biomass of seagrasses is known to be proportionally large (Duarte \& Chiscano in press), but its distribution within the sediments has not been examined for most species. Yet, differences in the vertical distribution of root and rhizome biomass among co-occurring species have been shown to be a major component of resource partitioning in land plants (Wilson 1988). In monospecific meadows, the depth distribution of the roots and rhizomes determines the environmental conditions (e.g. redox potential, nutrient concentrations) in which they grow and the extent to which the carbon and nutrients they contain are buried in the sediments after tissue death. In mixed meadows, the depth distribution of the roots and rhizomes should set the potential for competition for sediment space, as observed for land plants, and the resources contained therein (McConnaughay \& Bazzaz 1991), in the same way that the spatial distribution of the seagrass canopies in the water column influences the extent of competition for light.

The paucity of estimates of the belowground production of seagrasses is even more acute. Estimates of rhizome growth are now becoming available (e.g. Duarte \& Sand-Jensen 1990, Duarte 1991, Gallegos et al. 1993), but estimates of root production are still very few, largely due to methodological difficulties (cf. Dennison 1990). The few available estimates are based on tagging of rhizomes and measurements of root formation on newly formed rhizomes (e.g. Jacobs 1979, Marbá et al. 1996), or techniques based on the plastrochrone interval concept (e.g. Patriquin 1973, Kenworthy \& Thayer 1984) The lagging approach is only feasible for seagrasses with rhizomes located near the sediment surface, underestimates root production due to growth after the marking period, and neglects the production of adventitious roots on the vertical shoots that most seagrass species have (e.g. Duarte et al. 1994). The approach based on the plastochrone concept (i.e. the time interval in between production of consecutive seagrass modules) has not been widely applied (e.g. Patriquin 1973, Kenworthy \& Thayer 1984) and has been recently redefined (Duarte et al. 1994).

Seagrasses have adventitious roots stemming from their horizontal rhizomes and, for some species, verti- cal stems (cf Kuo \& McComb 1989), which play an important role in nutrient acquisition. Because seagraiss production is often mutrient limited, root growth may receive a substantial aniount of the carbon fixed by the plants to maintain their capacity to acquire nutrients (e.g. Pérez et al. 1994). The carbon allocated to root production is also placed relatively deeply into the sediments, sometimes at considerable depths (e.g. up to $5 \mathrm{~m}$ as observed in a Thalassia testudinum meadow; Zieman 1972). Root decomposition is likely to be incomplete, and a substantial fraction of the carbon allocated to roots may be assigned to long-term burial in the sediments (e.g. Kenworthy \& Thayer 1984, Romero et al. 1994), contributing to the important part played by higher marine plants as major sinks of carbon in the ocean (Duarte \& Cebrián 1996)

Increased efforts towards the quantification of the belowground production and biomass of seagrass meadows, and biomass distribution in the sediments, are, therefore, needed to provide a more balanced knowledge of their role. We describe here seagrass root and thizome biomass, and their distribution in the sediments, in 3 mixed meadows, representative of different floras, located in the Spanish Mediterranean (Jonquet Cove), the Mexican Caribbean (Puerto Morelos), and the South China Sea (Bolinao, The Philippines). Based on the results, we estimate the total root area (equivalent to the leaf area index; units: $\mathrm{m}^{2} \mathrm{~m}^{-2}$ ) of the seagrasses. We then estimate, based on a novel approach using age determinations (Duarte et al. 1994), the root production of the species present in these meadows, as well as that in a Posidonia oceanica meadow adjacent to the mixed Mediterranean meadow and sampled for root and rhizome biomass, and that of a dense monospecific Thalassodendron ciliatum meadow sampled on the coast of Kenya. We use the results derived from this comparative study to test (1) whether the biomass and production of roots represents a significant percentage of the total biomass and production of the seagrass communities studied, (2) whether the roots of different species in multispecific meadows are vertically segregated, and (3) whether root size is scaled to the diameter of the rhizomes, which is a general descriptor of the size of seagrass species.

\section{METHODS}

Study sites. The seagrass meadows studied are located in the Spanish Mediterranean littoral (Jonquet Cove, $42^{\circ} 18.26^{\prime} \mathrm{N}, 3^{\circ} 18.11^{\prime} \mathrm{E}$ ), in The Philippines (Silaqui Island and Lucero, Bolinao, Pangasinan, $16^{\circ} 27^{\prime} \mathrm{N}, 119^{\circ} 55^{\prime} \mathrm{E}$ \}, in the Mexican Caribbean (Puerto Morelos, Quintana Roo, 20 51' N, 86 $55^{\prime} \mathrm{W}$ ), and on the coast of Kenya (Chale lagoon, $4^{\circ} 25^{\prime} \mathrm{S}$, 
$\left.39^{\circ} 30^{\prime} \mathrm{E}\right)$. The study in The Philippines was conducted in July 1993 in a mixed seagrass meadow growing on an extensive reef flat at Silaqui Island. This is a dense, productive (Table 1), albeit nutrientlimited (Agawin et al. 1996), mixed (Thalassia hemprichii, Enhalus acoroides, Cymodocea rotundata, Halodule uninervis, Syringodium isoetifolium, and Halophila ovalis) meadow growing on the coarse carbonate sands of the reef flat, where semidiurnal tides have a range of about $1 \mathrm{~m}$ (cf. Vermat et al. 1995). The study site in the Mexican Caribbean supports a shallow ( $2 \mathrm{~m}$ depth) mixed meadow growing over carbonate sand in a reef lagoon. This community is dominated by Thalassia testudinum mixed with Halodule wrightii and Syringodium filiforme (Table 1; cf. Gallegos et al. 1993,1994). The communities sampled in the Mediterranean were a shallow $(0.5 \mathrm{~m}$ depth) mixed meadow growing over a thin $(5 \mathrm{~cm})$ mud layer overlying a gravel bed, with similar densities of Cymodocea nodosa and Zostera noltii, and an adjacent, dense Posidonia oceanica meadow growing somewhat deeper in the same cove (Table 1 ; cf. Marbá et al. 1996, Cebrián et al. 1997). The meadow of Thalassodendron ciliatum studied grows in a shallow backreef lagoon $50 \mathrm{~km}$ south of Mombasa on the Kenyan coast, and was dense (Table 1) and highly productive (Hemminga et al. 1994a, b). The biomass partitioning and growth rates of horizontal rhizomes and vertical stems of this $T$. ciliatum population have been described by Duarte et al. (1996).

Seagrass sampling. Belowground organs of these mixed meadows were sampled by collecting a number
( 5 to 10, depending on local density) of replicate cores. A metal (stainless steel or aluminum) corer $50 \mathrm{~cm}$ long and $20.5 \mathrm{~cm}$ internal diameter was pushed into the sediments completely, thereby encompassing most of the root material, which is typically within the upper 2 to $40 \mathrm{~cm}$ of sediments (Fonseca \& Thayer 1990). The cores were gently extracted from the corer, transported to the laboratory on individual trays, and gently washed to remove the coarser sediment particles and loose debris, while preserving the position of the plants in the sediments. Using large scissors, the cores were sliced into sections 3 or $5 \mathrm{~cm}$ thick, depending on sediment compactness. Each section was placed on a sieve and gently washed until all sediment and debris was removed. The roots and rhizomes in each of the resulting sections were sorted by species, and dried overnight $\left(85\right.$ to $105^{\circ} \mathrm{C}$, depending on the sites and species) before weighing to the nearest $\mathrm{mg}$ or $0.1 \%$ of the sample weight whenever it exceeded $1 \mathrm{~g}$ dry weight. While the roots of different species in the meadows sampled in the Mediterranean and Caribbean were morphologically distinct, the identity of the roots present in the sections collected in the Philippine meadow could not always be unambiguously established due to the large number (6) of species present Hence, the seagrass cores collected in the Philippine meadow were not sliced, since identification was only possible by maintaining the roots attached to the rhizomes, which only allowed estimates of root biomass per unit area of each species. No attempts were made to estimate the biomass and vertical structure of the belowground organs of Posidonia oceanica and Tha-

Table 1. Shoot density, leaf plastochrone interval (PI), the number of horizontal rhizome internodes produced annually, and the rhizome and leaf production of the seagrass meadows sampled. Data recalculated from Gallegos et al. (1993, 1994), Vermaat et al. (1995), Marbá et al. (1996), Cebrián et al. (1997), Hemminga et al. (1994a), and Duarte et al. (1996)

\begin{tabular}{|c|c|c|c|c|c|}
\hline \multirow[t]{2}{*}{ Location and species } & \multirow{2}{*}{$\begin{array}{c}\text { Density } \\
\left(\text { shoots } \mathrm{m}^{-2} \text { ) }\right.\end{array}$} & \multirow{2}{*}{$\begin{array}{l}\text { Leaf PI } \\
\text { (d) }\end{array}$} & \multirow{2}{*}{$\begin{array}{l}\text { Horizontal internodes } \\
\text { produced (internodes } \mathrm{m}^{-2} \mathrm{yr}^{-1} \text { ) }\end{array}$} & \multicolumn{2}{|c|}{ Production (g DW m $\left.{ }^{-2} \mathrm{yr}^{-1}\right)$} \\
\hline & & & & Rhizomes & Leaves \\
\hline \multicolumn{6}{|l|}{ Mexican Caribbean } \\
\hline Thalassia testudinum & 510 & 14.2 & 9238 & 115 & 2323 \\
\hline Halodule wrightii & 2407 & 16.5 & 7898 & 51.7 & 746 \\
\hline Syringodium filiforme & 95 & 60.8 & 189 & 6.2 & 29.7 \\
\hline \multicolumn{6}{|l|}{ The Philippines } \\
\hline Thalassia hemprichii & 548 & 10.9 & 567 & 83.8 & 1511 \\
\hline Cymodocea rotundata & 171. & 11.4 & 35.5 & 5.4 & 199 \\
\hline Enhalus acoroides & 21 & 35.6 & 215 & 76.5 & 139 \\
\hline Halodule uninervis & 47 & 9.6 & 102 & 9.0 & 32.8 \\
\hline Halophila ovalis & 16 & 2.2 & 200 & 3.9 & 9.5 \\
\hline Syringodium isoetifolium & 109 & 33.2 & 90 & 3.6 & 53.6 \\
\hline \multicolumn{6}{|l|}{ Spanish Mediterranean } \\
\hline Cymodocea nodosa & 1700 & 19 & 3720 & 55 & 475.6 \\
\hline Zostera noltij & 2133 & 16.6 & 47195 & 130 & 291.8 \\
\hline Posidonia oceanica & 616 & 43 & 668 & 6.5 & 845.3 \\
\hline \multicolumn{6}{|l|}{ Kenya } \\
\hline Thalassodendron ciliatum & 800 & 8.6 & 3017 & & \\
\hline
\end{tabular}


lassodendron ciliatum, which are extremely tough and reach deep into the sediments, making coring very difficult. For these species, shoots and the associated rhizomes and roots were carefully excavated by SCUBA divers. This procedure was repeated in quadrats ( 3 and 6 , respectively) of about $0.1 \mathrm{~m}^{2}$ until enough material was collected to estimate root production. The samples were gently washed to remove sediments and debris and kept frozen until examined at the laboratory.

To estimate root production, additional cores ( 3 to 7 ), enough to contain 30 to 80 shoots of each of the species, were collected by inserting the metal corer $35 \mathrm{~cm}$ into the sediments. Detritus and sediments were gently washed off the cores to avoid root damage. The age of all shoots present in the sample was determined as the sum of the number of leaf scars on the shoots plus the number of standing leaves (Duarte et al. 1994). The number of internodes of the horizontal rhizomes contained in the sample was then counted, and the number and length of all roots attached to them, as well as the number of scars left by shed roots, were recorded (cf. Duarte et al. 1994) Similarly, the number and length of the adventitious roots stemming from the vertical shoots, as well as the number of scars left by shed roots, were recorded (cf. Duarte et al. 1994). The estimates of shoot age derived from the number of leaves produced over the shoot's life span were converted into days by using the known mean annual leaf plastochrone interval (i.e the mean time span in between production of consecutive leaves in a shoot) for these populations (cf. Gallegos et al. 1993, 1994, Vermaat et al. 1995, Marbá et al. 1996, and Duarte et al. 1996). Subsamples of rhizomes and roots, both on vertical shoots and on horizontal rhizomes, of each species were collected, their length and average diameter $(\mathrm{N}>20$ ) were measured, and then they were dried (85 or $105^{\circ} \mathrm{C}$ ) to constant weight to estimate the dry weight and surface area per unit root or rhizome length. These data allowed calculation of the total length and area of belowground organs per unit area $\left(\mathrm{m} \mathrm{m}^{-2}\right.$ and $\mathrm{m}^{2} \mathrm{~m}^{-2}$, respectively), as well as the fraction of the sediment volume they comprised.

Calculation of belowground vertical stratification and root production. The depth of the belowground organs within the sediments was summarized by the centroidal depth of the biomass distribution, derived by calculating the mean depth weighted by the biomass present in each sediment layer The extent of vertical segregation of belowground organs of the different species growing in mixed meadows was described by examining the vertical variability in the coefficient of variation of the biomass contributed by the different species to each sediment layer. High coefficients of variation indicate the presence of one or more species with a dominant contribution to total belowground biomass, whereas low coefficients of variation indicate a more even contribution of the different species to total belowground biomass (Agusti et al. 1991), thereby suggesting a higher probability of competition for sediment space and resources.

The approach to estimate root production was based on the coupling between the development of roots and internodes in seagrass rhizomes. Seagrass rhizomes grow through the sequential development of material (internodes) in between the insertion points of leaves (nodes). These internodes can bear 1 or 2 adventitious roots per internode, depending on the species, which, if shed, leave an identifiable root scar on the internode (Duarte et al. 1994). Hence, the production of roots can be estimated from the average weight of fully grown roots produced per internode and knowledge on the number of internodes produced annually (Duarte et al. 1994). For those species with differentiated vertical and horizontal rhizomes, the root production must be calculated separately for either type of rhizome, because the size and rate of formation of adventitious roots vary between them (Duarte unpubl. obs.). Further details on the architecture of seagrasses and the rationale for the estimation of seagrass growth and production from their growth patterns can be found in Duarte (1991) and Duarte et al. (1994).

Root production on horizontal rhizomes was calculated as the average length and weight of the fully developed roots produced per rhizome internode, and scaled to areal production whenever a value for rhizome production was available. Hence, root production on horizontal rhizomes per unit area (units: $g$ DW $\mathrm{m}^{-2} \mathrm{yr}^{-1}$ ) equals the product of the root biomass produced per node of horizontal rhizome and the number of horizontal internodes produced annually (Table 1). The production of roots on vertical rhizomes was estimated as the slope of a regression equation relating the total number of roots produced by the shoots (i.e. standing roots plus root scars) to shoot age, as suggested by Duarte et al. (1994). Whenever the formation of roots on vertical shoots did not follow a steady pattern (i.e. total root number on leaf shoots was independent of age, as in Posidonia oceanica and Thalassodendron ciliatum), the avcrage rates of formation and death of adventitious roots were estimated from the average ratios of the total number of roots formed, and those that had fallen off prior to sampling (i.e. the number of root scars), to shoot age. Root production on vertical shoots per unit area (units: $\mathrm{g} D W \mathrm{~m}^{-2} \mathrm{yr}^{-1}$ ) was then calculated as the product of shoot density, the number of vertical internodes produced per year per shoot, and the average root biomass produced at each internode of the vertical shoot. The species that lack vertical shoots produce roots only at the horizontal rhizomes (e.g. Enhalus acoroides, Zostera noltii, and Halophila ovalis in this study). 
Table 2. Root and rhizome diameter, biomass, and projected surface area, and the position of their center of gravity in the sediments $(\mathrm{cm})$ for the species studied (except Posidonia oceanica and Thalassodendron ciliatum). Values for seagrasses in The Philippines represent means from 2 sites

\begin{tabular}{|c|c|c|c|c|c|c|c|c|}
\hline \multirow[t]{2}{*}{ Location and species } & \multicolumn{2}{|c|}{ Diameter (mm) } & \multicolumn{3}{|c|}{ Rhizome } & \multicolumn{3}{|c|}{ Root } \\
\hline & Rhizome & Roots & $\begin{array}{c}\text { Biomass } \\
\left(\mathrm{g} \mathrm{DWm^{-2 }}\right)\end{array}$ & $\begin{array}{c}\text { Area } \\
\left(\mathrm{m}^{2} \mathrm{~m}^{-2}\right)\end{array}$ & $\begin{array}{l}\text { Mean depth } \\
(\mathrm{cm})\end{array}$ & $\begin{array}{c}\text { Biomass } \\
\left(\mathrm{g} \mathrm{DW} \mathrm{m}^{-2}\right)\end{array}$ & $\begin{array}{c}\text { Area } \\
\left(\mathrm{m}^{2} \mathrm{~m}^{-2}\right)\end{array}$ & $\begin{array}{l}\text { Mean depth } \\
(\mathrm{cm})\end{array}$ \\
\hline \multicolumn{9}{|l|}{ Mexican Caribbean } \\
\hline Thalassia testudinum & 5.8 & 1.54 & 192 & 1.35 & 9.8 & 97.3 & 0.89 & 14.1 \\
\hline Halodule wrightii & 1.2 & 0.23 & 15.7 & 0.65 & 2.75 & 14.7 & 0.09 & 6.4 \\
\hline Syringodium filiforme & 2.8 & 0.81 & 3.0 & 0.02 & 2.5 & 3.05 & 0.03 & 7.5 \\
\hline Total & & & 210.7 & 2.02 & & 115.05 & 1.01 & \\
\hline \multicolumn{9}{|l|}{ The Philippines } \\
\hline Thalassia hemprichii & 3.43 & 1.7 & 224 & 0.90 & 6.52 & 79.3 & 0.22 & \\
\hline Cymodocea rotundata & 2.87 & 1.3 & 35.0 & 0.04 & 3.47 & 24.7 & 0.12 & \\
\hline Enhalus acoroides & 13.2 & 3.5 & 93.5 & 0.06 & 7.65 & 58.7 & 0.6 & \\
\hline Halodule uninervis & 1.25 & 0.18 & 4.9 & 0.02 & 3.01 & 1.8 & $<0.01$ & \\
\hline Halophila ovalis & 1.09 & 0.82 & 0.7 & 0.002 & 2.1 & 0.2 & $<0.01$ & \\
\hline Syringodium isoetifolium & 2.18 & 0.57 & 0.9 & 0.016 & 2.8 & 1.2 & $<0.01$ & \\
\hline Total & & & 357.4 & 1.04 & & 165 & 0.95 & \\
\hline \multicolumn{9}{|l|}{ Spanish Mediterranean } \\
\hline Cymodocea nodosa & 1.92 & 0.78 & 136.5 & 0.37 & 7.2 & 91.5 & 0.62 & 14.1 \\
\hline Zostera noltii & 1.89 & 0.6 & 149.1 & 0.63 & 3.2 & 92.8 & 0.22 & 4.6 \\
\hline Total & & & 285.6 & 1.0 & & 184.3 & 0.84 & \\
\hline Posidonia oceanica & 7.6 & 1.8 & - & - & - & & & \\
\hline \multicolumn{9}{|l|}{ Kenya } \\
\hline Thalassodendron ciliatum & 5.3 & 0.91 & 115.1 & 0.18 & - & 128.3 & 0.64 & - \\
\hline
\end{tabular}

\section{RESULTS}

\section{Root and rhizome biomass and distribution}

The roots of the seagrass species examined varied greatly in thickness, from 0.18 to $3.5 \mathrm{~mm}$ (Table 2), which increased as the thickness of their rhizomes, a descriptor of seagrass size (Duarte 1991), increased ( $\mathrm{r}=0.92, \mathrm{p}<$ $0.001)$. Root and rhizome biomass were quite significant (>100 and $>200 \mathrm{~g} \mathrm{DW} \mathrm{m}^{-2}$, respectively) for the mixed meadows examined, with rhizome biomass often being comparable or greater than that of roots (Table 2 ). Belowground structures developed a considerable projected surface area, often exceeding $1 \mathrm{~m}^{2} \mathrm{~m}^{-2}$ when considering roots and rhizomes together, and they produced a dense web comprising several hundred meters of root material per square meter (e.g. 57 and $558 \mathrm{~m}$ of Thalassia testudinum rhizomes and roots, respectively, $\mathrm{m}^{-2}$ ). As a consequence, belowground structures occupied a substantial fraction of the substrate's volume (e.g. $21 \%$ for $T$. testudinum), suggesting potential for competition for sediment space and resources.

Examination of the distribution of seagrass belowground biomass in the sediments revealed considerable vertical stratification, with all of the belowground biomass being present within the top $40 \mathrm{~cm}$ of the sediment for the seagrass meadows studied, except for Enhalus acoroides and Posidonia oceanica roots, which reached so deep that their entire root biomass could not be effectively sampled. The dominant species in the Caribbean meadow, Thalassia testudinum, tended to have its biomass positioned deeper in the sediments than the accompanying species did (Fig. 1). The rhizomes of $T$. hemprichii and E. acoroides were also placed deeper in the sediment than those of the smaller species in the mixed Philippine meadow (Fig. 2). Similarly, Cymodocea nodosa roots and rhizomes tended, on average, to be placed deeper in the sediments than those of Zostera noltii in the Spanish Mediterranean meadow (Fig. 3, Table 2). The average depth occupied by the roots and rhizomes of the seagrasses examined, summarized by the calculated centroidal depth, ranged between 1 and $14 \mathrm{~cm}$, depending on the species (Table 2). Examination of the vertical stratification of seagrass belowground biomass suggests a tendency for the larger species to extend their belowground structures deeper into the sediments than smaller ones do (Table 2). This tendency for a size-dependent vertical segregation of seagrass belowground biomass was further supported by the significant positive correlation between the centroidal depth of rhizome biomass in the sediments and the thickness of seagrass rhizomes $(r=0.61, p<0.05)$, which is an indicator of seagrass size (cf. Duarte 1991).

There was, however, considerable overlap in the vertical distribution of the belowground biomass of 

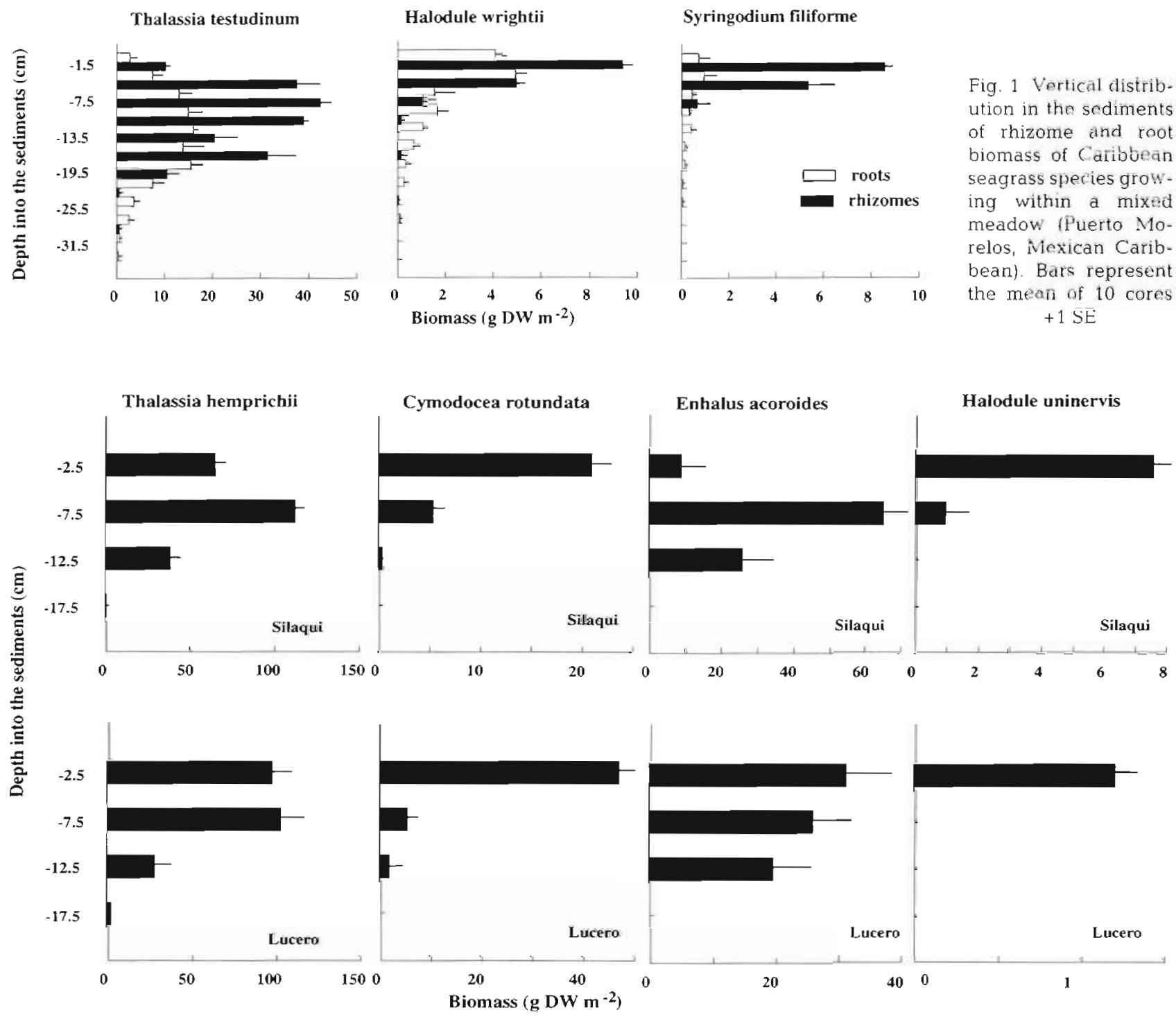

Fig. 2. Vertical distribution in the sediments of the rhizome biomass of the seagrass species growing within the 2 mixed Philippine meadows (Silaqui Island and Lucero, Cape Bolinao. The Philippines) sampled. Bars represent the mean of 5 cores +1 SE

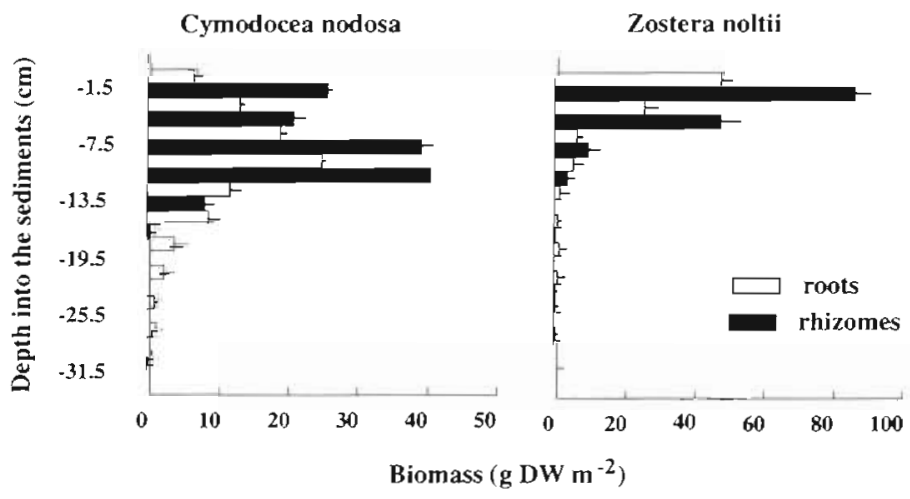

Fig. 3. Vertical distribution in the sediments of the root and rhizome biomass of the seagrass species growing within a mixed Mediterranean meadow (Jonquet Cove, NE Spain). Bars represent the mean of 5 cores $+1 \mathrm{SE}$ different seagrass species. The change in the partitioning of community biomass among species with sediment depth was evaluated using the coefficient of variation of species biomass in any one layer. The coefficient of variation of species biomass is an adequate descriptor of biomass partitioning, with minimal values indicating an even partitioning among species and high values indicating a biomass hierarchy where one, or a few, species dominate most of the biomass (Agustí et al. 1991). Examination of the vertical patterns in belowground biomass partitioning in the mixed meadows showed a tendency for a relatively even distribution of biomass among species (coefficient of variation $<1$ ) in the uppermost layers, and, for the Philip- 

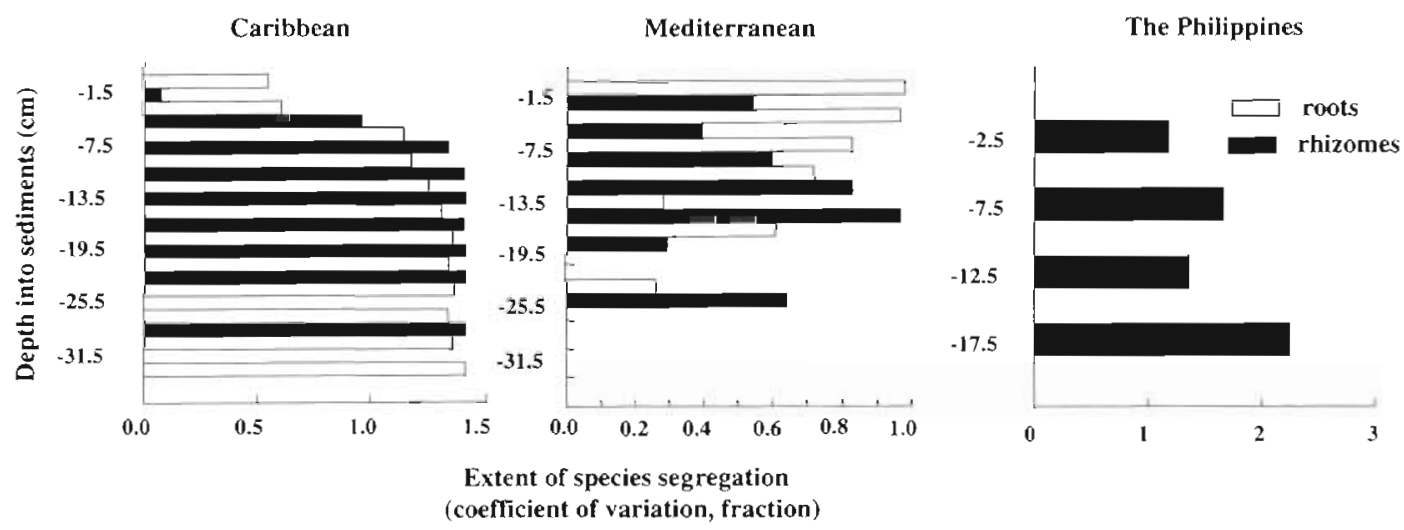

Fig. 4. Vertical distribution of the extent of segregation, as indicated by the coefficient of variation of the biomass among species within each of the sediment layers, of rhizome and root biomass of seagrass species growing within 3 mixed meadows

Table 3. Average number, weight and length of roots produced at nodes of horizontal rhizomes and vertical rhizomes (for those species which have differentiated vertical shoots) and the calculated root production in horizontal and, if applicable, vertical rhizomes

\begin{tabular}{|c|c|c|c|c|c|c|c|c|}
\hline \multirow[t]{2}{*}{ Location and species } & \multicolumn{3}{|c|}{ Horizontal Ihizomes } & \multicolumn{3}{|c|}{ Vertical shoots } & \multicolumn{2}{|c|}{ Root production } \\
\hline & $\begin{array}{l}\text { Roots } \\
\text { node }{ }^{-1}\end{array}$ & $\begin{array}{l}\text { mg DW } \\
\text { node }^{-1}\end{array}$ & $\begin{array}{c}\mathrm{cm} \\
\text { root }^{-1}\end{array}$ & $\begin{array}{l}\text { Roots } \\
\text { node } e^{-1}\end{array}$ & $\begin{array}{c}\text { mg DW } \\
\text { node }^{-1}\end{array}$ & $\underset{\text { root }^{-1}}{\mathrm{~cm}}$ & $\begin{array}{l}\text { Horiz. } \\
\text { (g DW m }\end{array}$ & $\begin{array}{l}\text { Shoots } \\
\left.-{ }^{-2} \mathrm{yT}^{-1}\right)\end{array}$ \\
\hline \multicolumn{9}{|l|}{ Mexican Caribbean } \\
\hline Thalassia testudinum & 0.31 & 88 & 7.8 & $0.65 \pm 0.03$ & 6.13 & 5.6 & 813 & 80.3 \\
\hline Halodule wrightii & 2 & 59 & 10.4 & $0.87 \pm 0.04$ & 1.04 & 3.4 & 466 & 55.3 \\
\hline Syringodium filiforme & 1.6 & 59.7 & 24.3 & $1.0 \pm 0.12$ & 1.82 & 2.5 & 11.3 & 1.0 \\
\hline \multicolumn{9}{|l|}{ The Philippines } \\
\hline Thalassia hemprichii & 0.32 & 47.1 & & $0.79 \pm 0.03$ & $34.9 \pm 37.2$ & 2.4 & 26.7 & 640 \\
\hline Cymodocea rotundata & 1 & 64.7 & & $0.22 \pm 0.03$ & $18.7 \pm 2.8$ & 10.7 & 2.3 & 102.4 \\
\hline Enhalus acoroides & 1 & 180 & 17 & & & & 38.7 & 0 \\
\hline Halodule uninervis & 2 & 7.8 & & & $1.8 \pm 0.3$ & & 0.8 & 3.2 \\
\hline Halophila ovalis & 1 & 4.0 & & & & & $<1.0$ & 0 \\
\hline Syringodium isoetifolium & 2 & 10.5 & & & $9.2 \pm 1.6$ & & $<1.0$ & 11.0 \\
\hline \multicolumn{9}{|l|}{ Spanish Mediterranean } \\
\hline Cymodocea nodosa & 0.6 & 5 & 21.3 & $0.36 \pm 0.03$ & 3.45 & 1.7 & 18.6 & 112.7 \\
\hline Zostera noltii & 3.4 & 8.2 & 3.2 & & & & 387 & 0 \\
\hline Posidonia oceanica & 0.27 & 16 & 43.1 & $0.099 \pm 0.01$ & 2.65 & 10.7 & 10.7 & 13.8 \\
\hline \multicolumn{9}{|l|}{ Kenya } \\
\hline Thalassodendron ciliatum & 1.35 & 28 & 10.7 & $0.07 \pm 0.01$ & $3.7 \pm 0.7$ & 7.9 & 84.5 & 125.6 \\
\hline
\end{tabular}

pine and Caribbean meadows, a tendency for the biomass to be dominated by 1 or 2 species deeper into the sediments (Fig. 4); this tendency was particularly strong for the Philippine meadow.

\section{Seagrass root production}

Root formation on horizontal rhizome internodes followed a consistent pattern within species, revealing a tight growth programme. Roots were present at every node in some species (e.g. Halodule spp., Zostera noltii), and only at a fraction of the nodes, generally those supporting vertical shoots, in some others (e.g. Thalassia spp., Posidonia oceanica; Table 3). More- over, the number of root meristems on horizontal nodes was fixed, and shed roots, which were identified by the presence of scars, were not replaced. The average weight of roots attached to each node varied greatly among species and independently of average root length (Tables 2 \& 3). Species with thick and long roots (e.g. Enhalus acoroides) supported much greater root biomass per rhizome node than species with thin, short roots (e.g. Halodule uninervis). Some species with relatively thin roots did, however, support a considerable root biomass per rhizome node (e.g. Cymodocea nodosa). This resulted from extensive root branching, while the roots of the larger species were not observed to branch (e.g. E. acoroides, P. oceanica and Thalassodendron ciliatum). 
The formation of roots on vertical rhizomes was examined by regressing the total number of roots produced (i.e. standing roots plus root scars) against shoot age. We found strong relationships between the number of roots produced and shoot age, indicative of a regular programme of adventitious root formation on vertical shoots for all species, except for Posidonia oceanica and Thalassodendron ciliatum, which showed a more irregular pattern (Fig. 5). The slope of these relationships (units: roots node ${ }^{-1}=$ roots leaf $s c a r^{-1}$ ) provide an estimate of the rate of adventitious root production on vertical shoots. The highest rates were observed in species that produced a root in almost every node, while some others (e.g. P. oceanica and $T$ ciliatum) produced 1 adventitious root for every 10 nodes produced (Table 3). Similarly, the average length of adventitious roots on vertical shoots was estimated from the slope of linear regressions between total root length per shoot and the number of standing roots (Table 3 ). These estimates were subsequently transformed into the average weight of individual adventitious roots by applying the specific root weight to the average root length obtained. The number and weight of standing adventitious roots tended to increase with increasing shoot age for all species examined $(p<0.005)$, except for $P$. oceanica and $T$. ciliatum. The average production of adventitious roots for these latter species was instead estimated from the average ratio between the total number of roots produced and shoot age. The average root length and weight of the individual adventitious roots of $P$. oceanica and $T$. ciliatum was estimated as the average ratio between their total length and weight per shoot, respectively, and the number of standing roots (Table 3).

The estimates of the rates of formation of roots on horizontal rhizomes and vertical shoots allowed calculation of root production. The estimates of root production obtained indicate root production-both on horizontal. rhizomes and vertical shoots - to be substantial in the meadows examined (Table 3 ). The combined root production in the mixed meadows approached, or exceeded, $1000 \mathrm{~g} \mathrm{DW} \mathrm{m} \mathrm{m}^{-2} \mathrm{yr}^{-1}$, and was much lower in the monospecific meadow (Table 3). The contribution of root production on vertical shoots versus that on horizontal rhizomes to total root production varied greatly, primarily reflecting differences in seagrass architecture (i.e. some species lack vertical shoots; Table 3).

\section{DISCUSSION}

Differences in root size among the species studied here were considerable, with the larger species (e.g.
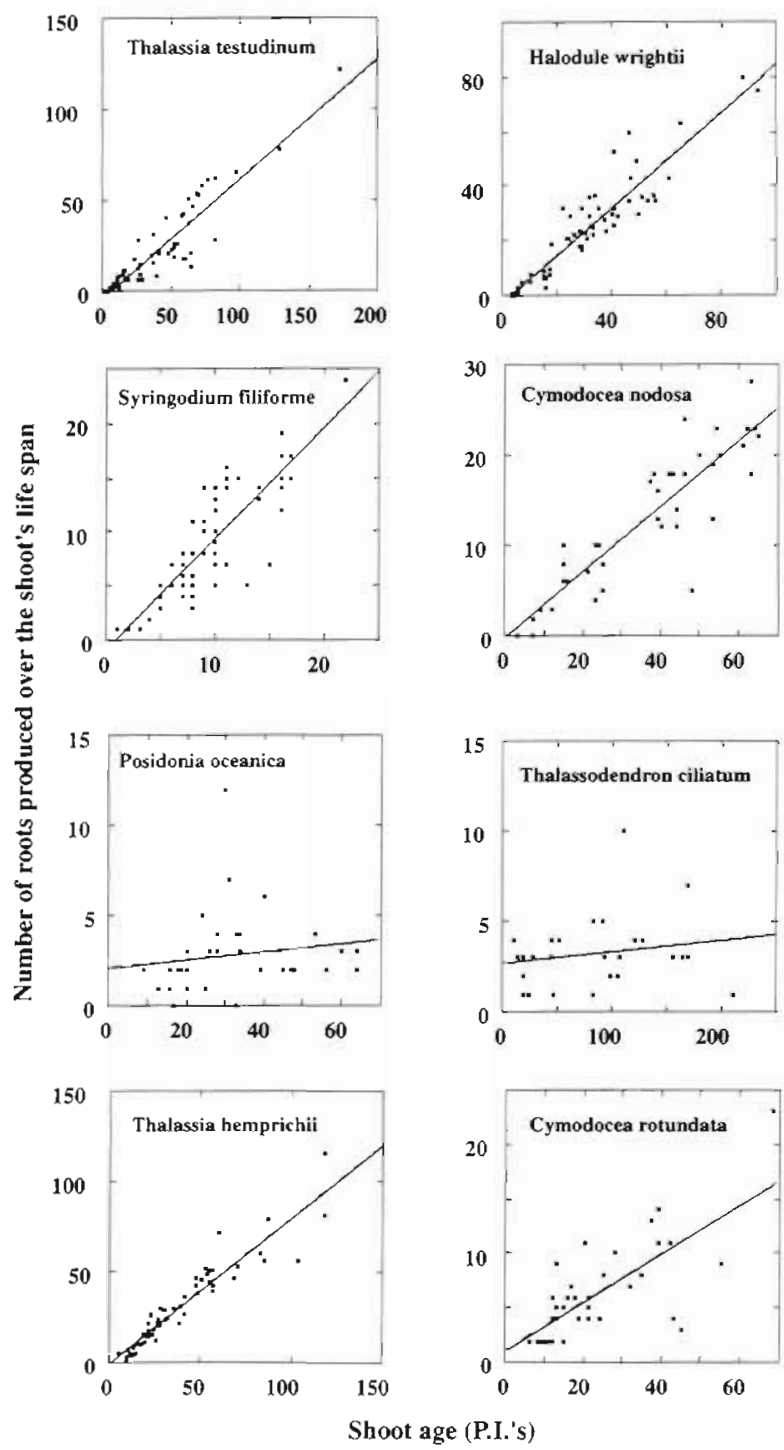

Fig. 5. Relationship between shoot age and the total number of adventitious roots produced (i.e. number of standing roots plus root scars) for the Caribbean, Mediterranean, Philippine, and Kenyan species examined

Enhalus acoroides, Posidonia oceanica, and Thalassia spp.) bearing thicker roots than the smaller ones in the stands sampled (Table 2); this indicates that the general scaling of the modules of seagrass species to the thickness of their rhizomes (Duarte 1991) applies to the roots as well. The fact that small seagrass species have thinner roots should result in a greater surface to volume (or biomass) ratio compared to roots of larger seagrass species. This observation suggests that nutrient uptake efficiency (i.e. uptake per unit root biomass) may be higher for small species, which also grow faster and have, therefore, greater nutrient demands per unit biomass. The thick roots of large species had substantial areal spaces (Duarte unpubl. obs.), suggesting that 
these species may be able to maintain a significant flux of oxygen to the roots from the photosynthetic structures. The suggested relationship between root thickness and function must, however, be verified empirically. The mean root length on horizontal rhizomes was consistently greater than the mean individual length of adventitious roots on vertical shoots (Table 3) The mean weight of roots per node varied between 10 - and 100 -fold for roots on vertical shoots and horizontal rhizomes, respectively, and was not clearly correlated with mean root length or seagrass size (Table 3). Hence, while the thickness of roots is scaled to general seagrass dimensions, their length appears to be influenced by other factors, presumably the extent of nutrient limitation of the species or the species' need for anchoring structures.

The biomass of roots on horizontal rhizomes reached its maximum development relatively fast $(<2 \mathrm{mo})$, and remained uniform or declined thereafter. All of the species that produce vertical shoots had adventitious roots on them, although this may not be applicable to all seagrass species, since we have not observed adventitious roots on shoots of Cymodocea serrulata, a species that produces long vertical shoots that extend into the water column (Vermaat et al. 1995). The biomass of adventitious roots on vertical shoots did not reach a steady state, since the number and total length of standing roots tended to increase with shoot age for most of the species examined. Old shoots have, therefore, a greater capacity to acquire sediment resources, and may play an important role as nutrient sources within the clone compared to young shoots, which have still undeveloped root systems and may act as sinks of resources instead (cf. Duarte \& Sand-Jensen 1996).

The belowground parts of the seagrass stands examined occupied the top 10 to $30 \mathrm{~cm}$ of the sediment, where rhizomes and roots may occupy a significant fraction of the available space (e.g $21 \%$ for Thalassia testudinum in the Caribbean community studied). Belowground structures may develop much deeper into the sediments ( $>1 \mathrm{~m}$ reached by $T$. testudinum rhizomes [Marbá et al. 1993] and up to $5 \mathrm{~m}$ by roots [Zieman 19721). The Mediterranean seagrass Posidonia oceanica forms a very dense network of roots, rhizomes, and attached leaf sheaths that can occupy most of the sediment volume (up to $80 \%$, Duarte unpubl. data), achieving reef-building capacity (Romero et al. 1994) where sediment particles are limited to the interstices of this network of seagrass material. The web of roots and rhizomes seagrasses produce can be compared to the leaf canopy through their projected areas (leaf area index and root or rhizome area indices, respectively; cf. Francour \& Semroud 1992). The projected area of belowground structures ranged between
0.18 and $3 \mathrm{~m}^{2}$ of rhizomes $\mathrm{m}^{-2}$ and 0.47 and $1 \mathrm{~m}^{2}$ of roots $\mathrm{m}^{-2}$ for the meadows investigated. These values are below those of typical seagrass leaf area indices of 2 to $18 \mathrm{~m}^{2} \mathrm{~m}^{-2}$ (Kuo \& McComb 1989) The projected root area reported represents a considerable potential absorptive surface, and may reach values considerably higher than those found here (up to $15 \mathrm{~m}^{2} \mathrm{~m}^{-2}$ for $P$. oceanica; Francour \& Semroud 1992).

The vertical distribution of rhizome and root biomass showed substantial stratification within the mixed meadows studied, showing, in general, an exponential decline in total rhizome and root biomass with depth (Figs. 1 to 3 ). There was some segregation in the sediment layers occupied by the belowground structures of the different species. The extent of overlap was greatest in the top $\mathrm{cm}$ of the sediment, with the number of species sharing a sediment layer decreasing from surficial layers to deeper ones (Figs. 1 to 4 ). The mean depth occupied by the belowground structures of the species studied ranged from very shallow (e.g. $2 \mathrm{~cm}$ for Halophila ovalis rhizomes) to $14 \mathrm{~cm}$ for Thalassia testudinum and Cymodocea nodosa roots (Table 2). The positive correlation between rhizome diameter, as a proxy for seagrass size (Duarte 1991), and the depth of the center of gravity of their rhizome biomass in the sediments indicated a tendency for larger species to occupy the deeper sediment layers used by the seagrass communities studied here, while surficial sediments are occupied by the smaller species. The vertical species segregation observed should reduce somewhat the potential competition for sediment resources, which should be greater in the uppermost layers, where the belowground biomass is more evenly distributed among species. The higher overlap in surface sediments results from the fact that, whereas the roots attached to horizontal rhizomes of large seagrass species tend to be placed deep in the sediments, the adventitious roots that arise from their vertical shoots extend all the way to the sediment surface, where they coexist with the rhizosphere of small seagrass species. The vertical distribution of roots among species also suggests that sediment nutrient uptake by small seagrass species is closely dependent on nutrients regenerated from recently deposited organic matter, whereas larger species can also exploit deeper nutrient pools regenerated from organic materials deposited decades, or centuries, ago. As a result, nutrient acquisition by roots of large seagrass species should be less closely matched to contemporaneous nutrient inputs than that of small seagrass species. The coexistence of roots of different species within the uppermost layers of the sediment indicates a potential for root competition, which has been shown to often exceed shoot competition in land vegetation (reviewed by Wilson 1988). The occurrence of mixtures of species whose roots 
occupy different layers in the soil has been shown to reduce competition and increase plant yield compared to that of monospecific stands or mixed stands of plants that occupy similar soil layers (Wilson 1988). This observation supports our contention that the vertical segregation of root biomass observed in the mixed seagrass meadows examined, with larger species occupying deeper sediment layers, should relax competition and increase community production, although these predictions must be subjected to experimental verification. Seagrasses may alleviate competition further by diversifying the nutrient sources, using both sediments and overlying waters.

The estimates of root production obtained are high, often exceeding $500 \mathrm{~g} \mathrm{DW} \mathrm{m}^{-2} \mathrm{yr}^{-1}$ (Tables $3 \& 4$ ). This high production is dominated by root growth on vertical shoots in some species, and by growth of roots on horizontal rhizomes in others (Table 2). We found no clear pattern in the variability of the relative contribution of these 2 types of roots to total root production, although there was a tendency for the Caribbean plants studied to allocate relatively more resources to root growth on horizontal rhizomes compared to other populations studied (Table 3). This may reflect the need for better anchorage in that hurricane-swept area (Marbá et al. 1993). The calculated turnover of the root compartment is relatively high, with most values ranging between 2 and $10 \mathrm{yr}^{-1}$, indicative of a characteristic turnover time of months for the root compartment (Table 4) and consistent with reports of fast turnover

Table 4. Total root production, the percent of total production encompassed by roots, and the calculated root turnover rate in the seagrass meadow examined

\begin{tabular}{|c|c|c|c|}
\hline Location and species & $\begin{array}{l}\text { Prod } \\
\text { (g DW } \\
\text { Roots }\end{array}$ & $\begin{array}{l}\text { uction } \\
\mathrm{m}^{-2} \mathrm{yr}^{-1} \text { ) } \\
\% \text { total } \\
\text { production }\end{array}$ & $\begin{array}{c}\text { Root } \\
\text { turnover } \\
\left(y^{-1}\right)\end{array}$ \\
\hline \multicolumn{4}{|l|}{ Mexican Caribbean } \\
\hline Thalassia testudinum & 893 & 26.8 & 9.1 \\
\hline Halodule wrightii & 521.3 & 39.5 & 35.4 \\
\hline Syringodium filiforme & 12.3 & 25.5 & 4.0 \\
\hline \multicolumn{4}{|l|}{ The Philippines } \\
\hline Thalassia hemprichii & 666.7 & 29.3 & 8.4 \\
\hline Cymodocea rotundata & 104.7 & 48.6 & 4.2 \\
\hline Enhalus acoroides & 38.7 & 15.2 & 0.65 \\
\hline Halodule uninervis & 4.0 & 8.7 & 2.2 \\
\hline Halophila ovalis & $<1.0$ & $<7.0$ & - \\
\hline Syringodium isoetifolium & 11.0 & 16.1 & 9.1 \\
\hline \multicolumn{4}{|l|}{ Spanish Mediterranean } \\
\hline Cymodocea nodosa & 131.3 & 19.8 & 1.4 \\
\hline Zostera noltui & 387 & 47 & 4.1 \\
\hline Posidonia oceanica & 24.5 & 2.8 & 0.13 \\
\hline \multicolumn{4}{|l|}{ Kenya } \\
\hline Thalassodendron ciliatum & 210 & & 1.6 \\
\hline
\end{tabular}

rates in root biomass of land plants (Hendricks et al. 1993). The estimates of root production derived here often exceeded those of rhizome production and reached values comparable to leaf production (Table 4), clearly demonstrating root production to be an important (up to $50 \%$ ) component of total production of seagrass (Table 4 ). The relative contribution of root production to net primary production of seagrasses is similar to the range reported for land plants (10 to $40 \%$ of net primary production; Hendricks et al. 1993). Our estimates of root production show, however, that seagrasses may allocate a sizable fraction of their production to roots. This is consistent with the fact that seagrass communities are often nutrient limited (e.g Short et al. 1990, Pérez et al. 1991, Agawin et al. 1996), and that nutrient-limited seagrass communities allocate proportionally more biomass to root growth (e.g. Pérez et al. 1994). The sizable production and turnover of seagrass roots suggests that considerable carbon and oxygen must be allocated to support root metabolism, since the carbon consumed by roots generally exceeds that needed to support their growth, particularly for species with fast-growing roots (cf. Poorter et al. 1991)

The high production and fast turnover of seagrass roots is in accordance with reports that fine roots are important components of the biomass and production of land plants (Gross et al. 1993. Hendricks et al. 1993). The production of marine angiosperms is typically assessed from the growth of seagrass modules (e.g. Dennison 1990), primarily that of leaves. The general neglecting of root production will lead to an underestimation of seagrass production by about 15 to $50 \%$ (Table 4). Hence, the role of seagrasses in marine primary production must be revised upwards from the current estimate of about $0.49 \mathrm{Pg} \mathrm{C} \mathrm{yr}{ }^{-1}$ (Duarte \& Cebrián 1996) to a more likely estimate of about 0.6 to $0.9 \mathrm{Pg} \mathrm{C} \mathrm{yr}{ }^{-1}$. Decomposition of roots is generally slower than that of leaves (Kenworthy \& Thayer 1984 , Enríquez et al. 1993), partially because of their lower nutritional quality (e.g. Kenworthy \& Thayer 1984, Enríquez et al. 1993, Pérez et al. 1994). Root material is, therefore, likely to be incompletely remıneralısed, particularly since roots are located deep in the sediments. An important fraction of root production, particularly that of species (e.g. larger species) that place their roots deeper into the sediments, may be buried in the sediments, as recently shown for deep-rooted grasses on land (Fisher et al, 1994). Hence, the widespread neglect of seagrass root production may have led to a gross underestimation of the role of seagrasses in sequestering atmospheric carbon (cf. Duarte \& Cebrián 1996). The approach and results provided here should, therefore, stimulate the examination of seagrass root production, and the fate of this produc- 
tion, as an important step to improve our knowledge of the production of seagrasses and their role in the global ocean

Acknowledgements. This research was funded by projects CI1 ${ }^{\circ}$-CT91-0952 and TS3 ${ }^{\circ}$-CT92-0114 from the Commission of the European Communities, grant 3216-T from the CONACYT, and a joint project of CSIC, the Spanish Ministry of Education, and CONACYT. We thank Aimé Rodriguez, Amaya Bermardez, and Pedro Ramirez for assistance in the field and laboratory.

\section{LITERATURE CITED}

Agawin NSR, Duarte CM, Fortes MD (1996) Nutrient limitation of Philippine seagrasses (Cape Bolinao, NW Philippines): in situ experimental evidence. Mar Ecol Prog Ser $138: 233-243$

Agustí S, Duarte CM, Canfield DE Jr (1991) Biomass partitioning within Florida phytoplankton communities. J Plankton Res 13:239-245

Cebrián J, Duarte CM, Marbá N, Enriquez S (1997) Magnitude and fate of the production of four co-occurring Western Mediterranean seagrass species. Mar Ecol Prog Ser 155:29-44

Dennison WC (1990) Rhizome/root production. In: Phillips RC, McRoy PR (eds) Seagrass research methods. Monographs on oceanographic methodology 9. UNESCO, Paris, p 81-82

Duarte CM (1991) Allometric scaling of seagrass form and productivity. Mar Ecol Prog Ser 77:289-300

Duarte CM, Cebrián J (1996) The fate of marine autotrophic production. Limnol Oceanogi 41:1758-1766

Duarte CM, Chiscano CL (in press) Seagrass biomass and production: a reassessment. Aquat Bot

Duarte CM. Hemminga M, Marbá N (1996) Growth and population dynamics of Thalassodendron ciliatum in a Kenyan back-reef lagoon. Aquat Bot 1-11

Duarte CM, Marbà N, Agawin NSR, Cebrián J, Enriquez S, Fortes MD, Gallegos ME, Merino M, Olesen B, SandJensen K, Uri J, Vermaat J (1994) Reconstruction of seagrass growth dynamics: technuques based on age determinations and associated tools for the seagrass ecologist. Mar Ecol Prog Ser 107:195-209

Duarte CM, Sand-Jensen K (1990) Seagrass colonization: patch formation and patch growth in Cymodocea nodosa. Mar Ecol Prog Ser 65:183-191

Duarte CM, Sand-Jensen K (1996) Nutrient constraints on establishment from seed and on vegetative expansion of the Mediterranean seagrass Cymodocea nodosa. Aquat Bot 54:279-286

Enriquez S, Duarte CM, Sand-Jensen K (1993) Nutrient regulation of plant decomposition rates: patterns across the plant kingdom. Oecologia $94: 457-471$

Fisher MJ, Rao IM, Ayarza MA, Lascano CE, Sanz JI, Thomas RJ, Vera RR (1994) Carbon storage by introduced deeprooted grasses in the South American savannas. Nature $371: 236-238$

Fonseca MS, Thayer GW (1990) Root/shoot ratios. In: Phillips RC, McRoy CP (eds) Seagrass research methods. Monographs on oceanographic methodology 9. UNESCO, Paris, p 65-67

Francour P, Semroud R (1992) Calculation of the root area index in Posidonia oceanica in the Western Mediterranean. Aquat Bot 42:281-286
Gallegos ME, Merino M, Marbá N, Duarte CM (1993) Biomass and dynamics of Thalassia testudinum in the Mexican Caribbean: elucidating rhizome growth. Mar Ecol Prog Ser 95:185-192

Gallegos ME, Merino M, Rodriguez A, Marbá N, Duarte CM (1994) Growth patterns and demography of pioneer Caribbean seagrasses (Halodule wrightii and Syringodium fillformel. Mar Ecol Prog Ser 109:99-104

Gross KI, Petersm A. Pregitzer KS (1993) Fine root growth and the demographic responses to nutrient patches in four oldfield plant species. Oecologia 95:61-64

Hemminga MA, Gwada P, Slim FJ, de Koeyer P, Kazungu J (1994a) Leaf production and nutrient contents of the seagrass Thalassodendron ciliatum in the proximity of a mangrove forest (Gazi Bay, Kenya). Aquat Bot 50:159-170

Hemminga MA, Huiskes AHL, Steegstra M, van Soelen $J$ (1996) Assessment of carbon allocation and biomass production in a natural stand of the salt marsh plant Spartina anglica using ${ }^{13} \mathrm{C}$. Mar Ecol Prog Ser 130 $169-178$

Hemminga MA, Slim FJ, Kazungu J, Ganssen GM, Nieuwenhuize J, Kruyt NM (1994b) Carbon outwelling from a mangrove forest with adjacent seagrass beds and coral reefs (Gazi Bay, Kenya). Mar Ecol Prog Ser 106:291-301

Hendricks JJ, Nadelhoffer KJ, Aber JD (1993) Assessing the role of fine roots in carbon and nutrient cycling. Trends Ecol Evol 8:174-178

Jacobs R (1979) Distribution and aspects of the production and biomass of eelgrass Zostera marina L., at Roscoff, France. Aquat Bot 10:241-259

Kenworthy WJ, Thayer GW (1984) Production and decomposition of the roots and rhizomes of seagrasses, Zostera marina and Thalassia testudinum, in temperate and subtropical marine ecosystems. Bull Mar Sci 35:364-379

Kuo J, McComb AJ (1989) Seagrass taxonomy, structure and development. In: Larkum AWD, McComb AJ, Shepherd $\mathrm{SA}$ (eds) Biology of seagrasses. Elsevier, Amsterdam, $\mathrm{p}$ $6-73$

Marba N, Cebrián J, Enríquez S, Duarte CM (1996) Growth patterns of Western Mediterranean seagrasses: speciesspecific responses to seasonal forcing. Mar Ecol Prog Ser $133: 203-215$

Marbá N, Gallegos ME, Merino M, Duarte CM (1993) Vertical growth of Thatassia testudinum: seasonal and interannual variability. Aquat Bot 47:1-12

McConnaughay KDM, Bazzaz FA (1991) Is physical space a solid resource? Ecology 72:94-103

McRoy CP, Barsdate RJ (1970) Phosphorus absorption in eelgrass. Limnol Oceanogr 15:6-13

Patriquin D (1973) Estimation of growth rate, production, and age of the marine angiosperm, Thalassia testudinum König. Caribb J Sci 13:111-123

Pérez M, Duarte CM, Romero J, Sand-Jensen K, Alcoverro T (1994) Growth plasticity in Cymodocea nodosa stands: the importance of nutrient supply. Aquat Bot 47:249-264

Pérez M, Romero J, Duarte CM, Sand-Jensen K (1991) Phosphorus limitation of Cymodocea nodosa growth. Mat Biol 109:129-133

Poorter H, van der Werf A, Atkin OK, Lambers H (1991) Physiol Plant 83:469-475

Romero J, Pérez M. Mateo MA, Sala E (1994) The belowground organs of the Mediterranean seagrass Posidonia oceanica as a biogeochemical sink. Aquat Bot 47:13-19

Short FT, Dennison WC, Capone DG (1990) Phosphorus-limited growth of the tropical seagrass Syringodium filiforme in carbonate sediments. Mar Ecol Prog Ser 62:169-174

Stevenson JC (1988) Comparative ecology of submersed 
grass beds in freshwater, estuarine, and marine environments. Limnol Oceanogr 33:867-893

Vermaat JE, Fortes MD, Agawin NSR, Duarte CM, Marbá N

Uri J (1995) Meadiow maintenance, growth, and productivity in a mixed Philippine seagrass bed. Mar Ecol Prog Ser 124:215-255

Editorial responsibility: Otto Kinne (Editor), Oldendort/Luhe, Germany
Wilson JB (1988) Shoot competition and root competition. J Appl Ecol 25:279-296

Zieman JC (1972) Origin of circular beds of Thalassia (Spermatophyta: Hydrocharitaceae) in South Biscaine Bay, Florida, and their relationship to mangrove hammock. Bull Mar Sci 22:559-574

Submitted: January 23, 1998; Accepted: July 7, 1998 Proofs received from author(s): September 11, 1998 